\title{
DIE GESKIEDENIS VAN DIE PERSONEELFUNKSIE IN DIE SA WEERMAG SEDERT WOI TOT 31 JANUARIE 1981
}

Kmdt J.J. du Toit*

\section{Inleiding}

Op versoek van H SAW is hierdie geskiedenis van die personeelfunksie geskryf ten einde dit as hulpmiddel te kan gebruik om tendense in die personeelveld te bepaal. Geen geskiedeniswerk kan ooit volledig wees nie. Daar moet 'n keuse gemaak word uit die totaliteit van feite wat uit bronne na vore gekom het. Ten opsigte van die geskiedeniswerk is daar dus baie wat ongesê gebly het en kan dit hoogstens as ' $n$ horisontale of oorsigtelike geskiedenis gekarakteriseer word. Elke aspek wat behandel is kan die onderwerp van 'n diepte-ondersoek en 'n aparte indringende studie word. Sekere feite het waarskynlik onvermeld gebly bloot uit gebrek aan voldoende argiefmateriaal en tyd om daarna te soek.

\section{Doel}

Om die geskiedenis van die personeelfunksie vir die SAW so te boekstaaf dat tendense vir die pesoneelveld daaruit afgelei kan word.

\section{Bestek}

Die geskiedenis van die personeelfunksie is beskryf in die volgende fases:

(a) Fase 1: Die tydperk tussen WO I tot die einde van WO II.

(b) Fase 2: Vanaf die einde van WO II tot die einde van 1975.

(c) Vanaf 1976 oor die tydperke van elke Hoof van Staf Personeel.

(i) Fase 3: 1 Jan 1976 - 30 September 1977: Lt genl P.A. le Grange.

(ii) Fase 4: 1 Oktober 1977- 31 Januarie 1980: v Adm R.A. Edwards.

(iii) Fase 5: 1 Februarie 1980 - 31 Januarie 1981: Lt genl G.J.J. Boshoff.

Benadering. Die geskiedenis word uit die volgende hoeke benader:

(a) Bevel en beheer.

(b) Mannekragsituasie. (c) Bemanning.

(d) Instandhouding.

\section{Fase 1: WO I tot EINDE WO II}

\section{Bevel en beheer}

Met die totstandkoming van die Unieverdedigingsmag in 1912 het die personeelfunksie ten opsigte van militêre personeel geresorteer onder die Afdeling van die Generale Staf. Die Verdedigingswet (Wet No 13 van 1912) het vir die instelling van onder andere 'n Administratiewe Staf vir die militêre distrikte en subdistrikte voorsiening gemaak, (artikel 30). Dit het onder die regstreekse beheer van die Stafoffisier vir Administratiewe Pligte geval. Die administrasie van verdedigingsake, insluitende dié van die burgermag- en vrywilligersorganisasies van die vier kolonies wat na 1910 die Unie gevorm het en tot 1912 deur ' $n$ afdeling van die Departement van Binnelandse Sake beheer is, is daardeur gemilitariseer.

Gedurende die Eerste Wêreldoorlog is die SuidAfrikaanse magte se administrasie op operasionele vlak deur die Britse Leër behartig, en daar het geen verdere uitbreidings plaasgevind nie. Noemenswaardig in daardie tydperk was die amptelike verandering vanaf Maart 1916 van die benaming van die Stafoffisier vir Administratiewe Pligte na Kwartiermeester-generaal.

Gedurende 1917 is die pos Stafoffisier, Generale Staf hernoem na Hoofstafoffisier, Generale Staf en Adjudant-generaal (AG) en het dus ' $n$ "dubbelhoed" aanstelling gehad. Hierdeur is die personeelfunksie tog erken as afsonderlike staffunksie. In die tydperk tussen die twee Wêreldoorloë het daar wat administratiewe dienste betref, ingrypende organisatoriese veranderinge plaasvind.

Die pos van AG is op 5 Junie 1918 van die HGS geskei. Daardeur het die Afdeling Personeel 'n volwaardige, selfstandige afdeling geword. 
Met die hersamestelling van die Staande Mag in 1923 het daar naamlik onder andere die volgende drie korpse tot stand gekom:

(a) Die Suid-Afrikaanse Intendanskorps.

(b) Die Suid-Afrikaanse Krygsbehoeftediensdorps.

(c) Die Suid-Afrikaanse Administratiewe-, Betaal en Klerklike Dienskorps.

In 1939 is besluit om sowel die Intendanskorps, as die Krygsbehoeftedienskorps en die Administratiewe-, Betaal en Klerklike Dienskrops te ontbind, en al drie saam te voeg in 'n enkele SuidAfrikaanse Administratiewe Korps onder die Kwartiermeester-generaal. Dit is binne ' $n$ maand herdoop as die Krygsdiensdorps 'Q Services Corps'. In praktyk het die Adjudant-generaal egter steeds saam met die Kwartiermeestergeneraal sy beheer oor administratiewe dienste in die Unieverdedigingsmag behou.

Die uitbreek van die Tweede Wêreldoorlog het ook uitbreiding van die personeelfunksie genoodsaak. Gedurende 1942 is die pos van AG opgegradeer na generaal-majoor. Dit kan gesien word as ' $n$ erkenning van die toenemende belangrikheid van die personeelfunksie.

Die afdeling van die AG was teen 1946 georganiseer in ' $n$ reeks ongekoördineerde afdelings wat deur die Adjunk AG (Adj AG) en die AG beheer is. Die verantwoordelikhede van die Adj AG was so uitgebreid dat dit nouliks hanteerbaar was. Gevolglik is daar besluit om sekere personeel-onderafdelings (AG1: Offisiere, AG4: Ander Range, AG2: RAG (Regteradvokaat-generaal), AG5: Onderskeidings en Toekennings, HBM sowel as die Kapelaansdienste, direk onder beheer van die AG te plaas.

\section{Mannekragsituasie}

Die totale sterkte van die Staandemag was op 1 April 1913, 2043 man, alle range ingesluit. Agv die noodsaaklike besuinigings gedurende depressie is offisiere in die Staandemag afgedank voor hul normale aftrede en vakante poste is nie gevul nie. Verder is salarisse verminder en bevorderings is gedoen sonder salarisverhogings. Die aanbod van mannekrag het egter steeds die aanvraag by verre oorskry.

Vanaf 1 April 1934 met die herstel van die ekonomiese situasie is weer begin om die Staandemag uit te brei en is daar weens die tekort aan offisiere, besluit om BM offisiere vir 3 jaar aan te stel (kortdiensstelsel).

Met die uitbreek van die oorlog in 1939 het die Unieverdedigingsmag uit $40 \%$ Staandemag en $60 \%$ aktiewe Burgermag bestaan. Op 22 Sept 1939 is magtiging aan die Aktiewe Burgermageenhede verleen om vrywilligers vir die duur van die oorlog te aanvaar.

Agv beswaar dat die Verdedigingswet nie van die Unie Verdedigingsmag verwag om te dien behalwe ter verdediging van Suid-Afrika nie en daar probleme ondervind is om die grens van Suid-Afrika te definieer, moes die Aktiewe Burgermag herorganiseer word op die basis dat vrywilligers onderneem om enige plek in Afrika te dien.

\section{Bemanning}

Gedurende die jare 1913-1926 is gevind dat mense wat aangemeld het vir diens in die Staandemag, nie oor die nodige opvoeding of die nodige intelligensie beskik het om die pligte te kan uitvoer nie. Van die burgers tussen die ouderdomme van 17 en $21 \mathrm{jr}$ wat moes registreer het $83 \%$ egter aangedui dat hulle bereid was om vir vrywillige diens opgelei te word. Slegs genoeg vrywillige burgers is aanvaar om die tekorte by al die Eenhede aan te vul. Weens die tekort aan offisiere is ' $n$ kortdiensstelsel geïmplementeer waardeur lede van die BM vir 3 jaar in die Staandemag aangestel kon word.

\section{Instandhouding}

Met die amalgamasie van die agt verskillende magte wat onder verskillende wette in die ou kolonies bestaan het is groot probleme ondervind om eenvormige diensvoordele tot almal se tevredenheid te bewerkstelig. Die riglyn van die Parlement was dat geen lid van die magte swakker daaraan toe mag wees wat soldy betref nie. Ontevredenheid het egter ontstaan by diegene wat, alhoewel hulle bevoordeel is, nie in dieselfde mate as ander bevoordeel is nie. Ten einde beter bevorderingmoontlikhede gedurende die depressie te bewerkstellig is die Staandemag vir doeleindes van ansiënniteit en bevordering gegroepeer in gevegsoffisiere en nie-gevegsoffisiere. Verder is gevegsoffisiere onderverdeel in offisiere van die SA Stafkorps en ander gevegsoffisiere. Dit kan gesien word as die begin van beroepsdifferensiasie in die SAW. 
Fase 2: Einde Wo II tot einde van 1975

\section{Bevel en beheer}

Die drie Stafhoofde tesame met die AG, KMG en GG het die HGS na WO II bygestaan in sy pligte. Die grootste taak vir die personeelfunksie was die demobilisasie na die oorlog. Die personeelfunksie was nog nie as sulks geïdentifiseer nie, maar die noodsaaklikheid daarvan is bevestig toe die Minister van Verdediging F.C. Erasmus in 1949 , in 'n persoonlike nota aan die Hoof van die Generale Staf sy wens uitspreek dat die Krygsdienskorps se naam verander moes word na Administratiewe Dienskorps. Die suggestie is opgevolg deur die Proklamasie 310 van 1949 uitgevaardig deur die destydse Goewerneurgeneraal.

VERGELYKENDE STERKTES : 1939/1978/1980
90000

$30000-$

20000

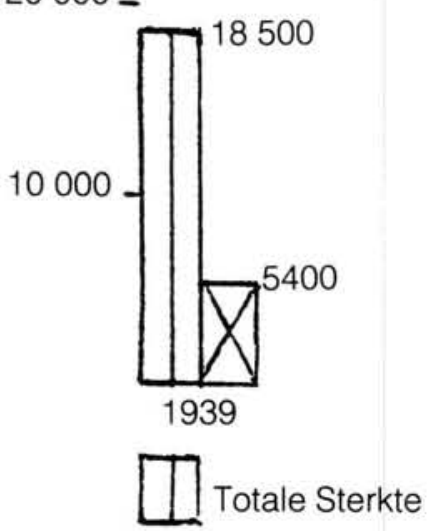

$80000-$
104000
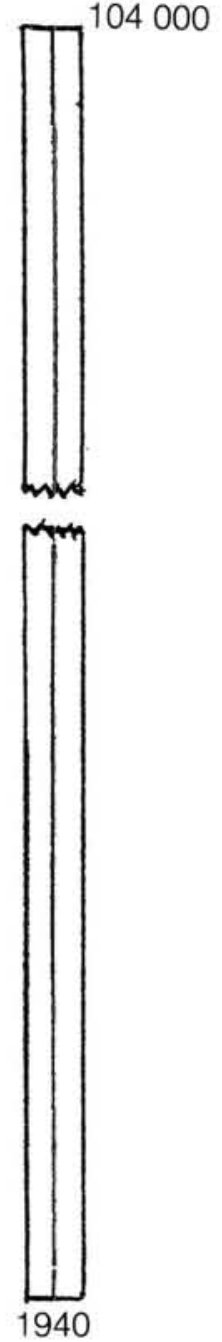

$\mathrm{Na}$ aanleiding van wrywing tussen die Kwartiermeester-generaal, Adjudant-generaal en die Direkteur-generaal Landmagte het Kwartiermeester-generaal voorgestel dat Adjudant-generaal die beheer oor administratiewe- en tegniese personeel oorneem. Dit het in Augustus 1950 gebeur.

$\mathrm{Na}$ die bewindverandering in 1948 was daar ' $n$ tydperk van sentralisasie van bevel en beheer weens die gevaar van ondermyning en sabotasie van die personeelfunksie deur andersdenkendes.

Die belangrikheid van ' $n$ doeltreffende personeelfunksie het tot gevolg gehad dat in die tydperk 1951 tot 1957 daar vyf pogings aangewend
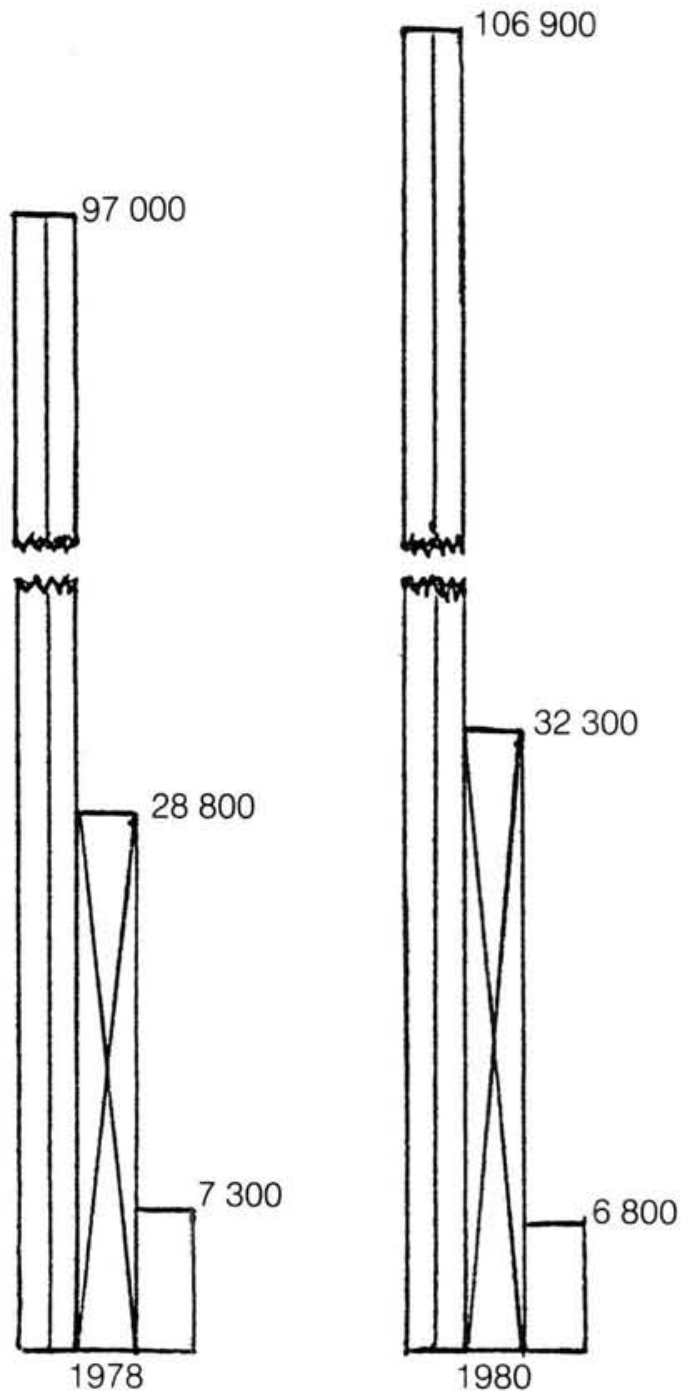

Mag Sterkte Burgerlikes 
is om die Administratiewe Dienskorps in sy belangrikste samestellende elemente, naamlik Administrasie en Krygsbehoeftes te verdeel en die administratiewe personeel onder beheer van die Adjudant-generaal te plaas en die Krygsbehoefte personeel onder beheer van die Kwartiermeester-generaal. Daar is destyds egter bevind dat sodanige voorstelle prakties bykans onuitvoerbaar was omdat dit 'n grootskaalse herskommeling en hergradering van poste sou meebring, loopbaanvooruitsigte van die betrokke personeel sou verswak en derhalwe is dit elke keer laat vaar.

Die Adjudant-generaal se beheer oor die Administratiewe Diensdorps is daarna egter inderdaad vergroot. Die Korps was gemoeid met administrasie, finansies, voorraad, ammunisie, bevoorrading en transport, orkeste, betalingdienste en verplasing. Professionele offisiere soos bibliotekarisse, regsoffisiere en argitekte moes ook in die Korps 'n tuiste vind.

Die grootste enkele belemmerende faktor vir die uitvoering van die personeelfunksie in daardie tydvak was geïdentifiseer $\mathrm{nl}$ die sekretariaat van die Dept Verdediging wat die kanaal was tussen die Weermag se personeelfunksie en die Staatsdienskommissie. Alle aanbevelings na die Staatsdienskommissie moes deur die Sekretaris van Verdediging gekanaliseer word. Agv die onkunde tov Weermagaangeleenthede en die gesag wat by die Sekretariaat gevestig was, is aanbevelings na willekeur deur die sekretariaat afgekeur of in 'n ander formaat aan die Kommissie voorgelê. Hierdie probleem het aanleiding gegee tot die ondersoek van die verdeling van die funksies van die Dept Verdediging deur die Verster-komitee in 1966 en die uiteindelike afskaffing van die Sekretariaat van Verdediging. Verder is die ampstitel van die AG verander na Hoof van Weermagadministrasie (HWA).

Die snelle uitbreiding van die SAW en die eskalerende bedreiging het die belangrike inslag van hoëvlak personeeladministrasie beklemtoon. Gedurende 1970 is werksaamhede mbt hoëvlakpersoneelsake, algemene administrasie, doeltreffendheidstudies en KMG-aangeleenthede na die HWA gedelegeer en die posbenaming van Hoof van Personeel by die HWA is verander na DG Personeel.

Die HWA het op daardie stadium uit ' $n$ vierbeen beheerliggaam bestaan waarby ingesluit was DG Personeel, KMG, DG Algemene Administrasie en DG Bestuursdienste. In 1971 het Direk- teur-generaal Personeel ook by die Hoof van die Leër aanbeveel dat die Adm Dienskorps met vrug in die volgende sub-indelings, waarvoor gepaste benamings mettertyd gevind kon word, verdeel kon word, naamlik:

(a) die suiwer administratiewe tak;

(b) die voorradetak;

(c) die betaalmeesterstak; en

(d) die rekenkundige tak.

Agv die steeds eskalerende bedreiging moes die Weermag steeds uitbrei en is doeltreffende personeelfunksie as 'n noodsaaklikheid beskou. Op $15 \mathrm{Apr} 74$ is die pos van HWA afgeskaf en die DG Personeel as Hoof van Staf Personeel direk aan die Hoof van die Weermag verantwoordelik gemaak vir die uitvoering van die personeelfunksie in die SAW. HBM wat onder die DG Personeel geresorteer het is afgedeel na die Komptroleer, SAW. Verder is die onderafdeling Regteradvokaat-generaal sedert April 1975 as Direktoraat Militêre Regspleging by HSP Ingeskakel. HSP is aangewys as die Korpsbevelvoerder van die Korps van Professionele Offisiere en die Militêre Akademie, SAVK, Kolot en die personeel van die onderskeie indiensnemingsentrums is onder funksionele beheer van HSP geplaas.

Die belangrikheid van die suiwering van die personeelfunksie is weer bevestig toe die Administratiewe Dienskorps van die Leër op aanbeveling van die Coetzerkomitee in 1975 in 'n Personeeldienskorps en 'n Krygsbehoeftedienskorps verdeel is. Eersgenoemde moes gestig word uit lede van die Administratiewe Dienskorps wat met personeel- en algemene administrasie gemoeid was. Hulle moes in personeelbestuur spesialiseer, en moes die nodige spesialisopleiding in daardie rigting ontvang.

Die HSP het aanbeveel dat professionele offisiere, naamlik argivarisse, krygshistorici, militêre regsoffisiere, stafoffisiere militêre museums, vryetydsbestedingsoffisiere, terminoloë, stafoffisiere publikasies, dosente, burgerleidingoffisiere, sport- en liggaamlike opleidingsoffisiere, programmeerders en werkstudieoffisiere in 'n Korps van Professionele Offisiere onder beheer van Hoof van Staf Personeel ingedeel word. Hierdie aanbevelings is aanvaar, en ministeriële goedkeuring is verleen vir die ontbinding van die Administratiewe Dienskorps met afsluiting van diens op 31 Julie 1975. Die volgende nuwe korpse het met ingang 1 Augustus daaruit ontstaan: 
(a) Personeeldienskorps.

(b) Krygsbehoeftedienskorps.

(c) Korps van Professionele Offisiere.

\section{Mannekragsituasie}

$\mathrm{Na}$ die beëindiging van die Tweede Wêreldoorlog en demobilisasie is die SAW wat sy getalsterkte betref in 1946 drasties ingekrimp. In die lig van oplaaiende dreigemente van buite is daar in 1960 op 'n opknapping en uitbreiding van die Weermag besluit.

Gedurende 1965/66 is daar egter 'n ernstige tekort aan mannekrag in die Staandemag beleef en die aantal burgerlikes wat in Staandemag poste aangestel moes word moes met $50 \%$ verhoog word. Teen 1969 is gevind dat die doeltreffendheid van die SAW benadeel word deur ' $n$ hoë omset van opgeleide Staandemag personeel aan die privaat sektor. Verbeterde diensvoorwaardes en voordele is ingestel en vanaf 1969 tot 1972 het die omset van offisiers van $7,9 \%$ na $5,9 \%$ gedaal en die van manskappe van $13,9 \%$ na $11,1 \%$. Verder is egter gevind dat die werwing van 1 rekruut nie die verlies van 'n opgeleide lid kan opmaak nie. 'n Komitee is aangestel om meer doeltreffende werwing te ondersoek.

Gedurende die tydperk 1972 tot 1974 het die personeelomset egter weer gestyg van $5,9 \%$ na $7,9 \%$ in die geval van offisiere en na $14,9 \%$ in die geval van manskappe. Daar het egter globaal ' $n$ sterktevermeerdering plaasgevind agv ' $n$ toename in nuwe rekrute. Getoets teen die uitbreiding van die goedgekeurde sterktetabelle was die offisiersterkte besig om na 'n potensiële gevaarpunt te beweeg terwyl die personeelverliese in die manskapgeledere die aanwas oorskry het.

In 1974 is in die betrokke Witskrif geskryf:

\footnotetext{
"Although we may possess the most modern and sophisticated weapons and equipment, we would still not be proof against attack or internal disintegration if the men and women who have to handle and maintain the weapons and equipment did not possess the right inspiration, dedication, physical qualities and specialized training" en is die primêre belangrikheid van die personeelfunksie vir die SAW weer eens beklemtoon.
}

\section{Bemanning en ontwikkeling}

Dienspligstelsel. Gedurende 1966 het die Groenewoudkomitee aanbevelings gemaak ten einde die tekortkominge van die bestaande lotingstelsel uit die weg te ruim, en is die Nasionale Dienspligstelsel geïmplementeer waarvolgens elke medies geskikte manlike burger verplig is tot militêre diens. In 1973 is die aanvanklike diens van 9 maande verleng na 10 maande aangesien die bedreiging genoodsaak het dat ' $n$ parate mag konstant gereed moes wees om op enige plek waar nodig aangewend te word.

Gedurende 1974 is die aanvanklike opleiding-en dienstydperk gestandardiseer tot 'n minimum van een jaar. Die innames is gerasionaliseer tot 2 innames per jaar.

Vroue en Anderskleuriges. Ten einde die mannekragnood te verlig is oorgegaan tot die emplojering van vroue in die Staandemag. Kleurlinge is reeds jare gebruik en aandag is aan die aanwending van Indiërs en Swartes gegee. Die eerste groep Indiërs en Swartes het in 1974/75 met opleiding begin.

\section{Fase 3: Lt GenI P.A. le Grange SSA, SM: Jan 1976 - Sep 1977}

Lt genl Le Grange was egter reeds sedert 1974 aangestel as die HSP. Die geskiedenis oor die tydperk 1974 tot 1975 is reeds in die voorafgaande bespreek.

\section{Bevel en beheer}

Soos die geval was sedert 1974 was die personeelfunksie van die SAW onder die bestuur van die HSP wat direk aan die HSAW verantwoordelik was. Hierdie situasie het tot op hede onveranderd gebly.

Personeeladviesraad. Agv die behoefte om interaktiewe personeelbeleidaspekte te formuleer en te reguleer en oplossings te vind vir gemeenskaplike probleme ivm personeelbestuur is die SAW Personeeladviesraad op 27 April 1977 ingestel. Die HSP het as voorsitter opgetree en al die personeelbestuurders van die Weermagsdele, en AMI het sitting daarop gehad.

\section{Mannekragsituasie}

Gedurende hierdie termyn het die SAW hom wat personeel betref, nog in ' $n$ moeilike posisie be- 
vind. Daar was nog steeds 'n onrusbarende uitvloei van opgeleide lede alhoewel daar aan die ander kant agv 'n verskerpte werwingveldtog 'n aanwas in getalle was.

\section{Bemanning}

Op 4 Augustus 1976 het die W/HSAW opdrag gegee dat ' $n$ komitee saamgestel word om ondersoek na 'n optimale mannekragvoorsieningstelsel vir die SAW in te stel, met insluiting van die moontlikhede van ' $n$ groter Staandemag en ' $n$ verlenging van die nasionale dienspligtermyn. (OPMAN-KOMITEE).

Die OPMAN-KOMITEE se verslag is in Februarie 1976 uitgebring met die volgende aanbevelings:

(a)Basiese Mannekragvoorsieningstelsel. Daar is gevind dat die toekomsbeeld 'n situasie van voortdurende operasionele eise van eskalerende en de-eskalerende intensiteit aan die SAW gaan stel.

(b) Staandemag. 'n Aansporingstelsel om diensverlenging in die Staandemag te bevorder moes ingestel word. Verder is ' $n$ Staandemag magspeil van 41327 plus ' $n$ burgerlike komponent van 11581 in die langtermyn 1981-1987 aanbeveel. Dws Staandemag $13,8 \%$ en burgerlikes $3,9 \%$ van die totale Weermagsterkte.

(c) Kortdiens. 'n Deel van die voltydse komponent kan deur 'n kortdiens SMag-stelsel voorsien word. Hierdie stelsel is reeds gedurende 1977 geïmplementeer.

(d) Nasionale Diensplig. Die verlenging van die dienspligtermyn na 24 maande aanvanklike ononderbroke diens.

(e) Burgermag. Die huidige dienspligtydperk van 10 jaar moes behoue bly.

Die werwingfunksie van die SAW is gedurende hierdie termyn gedesentraliseer na streekkantore in Pretoria, Johannesburg, Port Elizabeth, Durban en Kaapstad onder beheer van die HSP.

\section{Instandhouding}

Agv die uitbreiding van die SAW het die doeltreffende uitvoering van die personeelfunksie van kardinale belang geword. Agv die grootte van die SAW en die doeltreffendheidvereiste is delegasie van personeelfunksies nav die Verdedigingswet, AR en administratiewe voorskrifte her- sien. Die Weermagsdele se behoeftes het as riglyn gedien ten einde funksies te delegeer. Die kontrolefunksies het egter by HSP gesentreer. Die doel was:

(a) om die magtiging vir die neem van beslissings tot op die mees effektiewe vlak te desentraliseer en

(b) die delegasies op 'n geordende, logiese wyse aan te bied.

Verder is 'n projek vir die daarstelling van ' $n$ geïntegreerde rekenaardatabasis vir SAW-personeel geïnisieer (Projek PERSBINS).

Ten einde doeltreffendheidsevaluering vir die SAW in te stel is ' $n$ ondersoek na die voorsiening van 'n Inspekteur-generaalafdeling vir die HSAW en die geveg- en ondersteuningdienste gedoen.

Die eerste prosesse in die daarstelling van 'n militêre mannekragplan, $\mathrm{nl}$ behoeftebepaling, is deur die OPMAN-komitee voltooi. Daar is ook vordering gemaak met die tweede proses $\mathrm{nl}$, die daarstelling van kwantitatiewe en kwalitatiewe mannekraginventarisse.

Verder is ' $n$ Projek geloods om 'n wiskundige model te ontwikkel om die uitwerking van werwing- bevordering- en uitdienstredingbeleid op die SAW rangstruktuur te bepaal (Projek RYTUIG).

'n Eenvormige liasseerstelsel wat ingestel is het meegebring dat alle Gevegs-, Ondersteuningsdienste en Stafafdelings dieselfde verwysing op korrespondensie gebruik en liassering is daardeur tot ' $n$ groot mate vereenvoudig.

'n Verdere projek is aangepak om volledige kennis van die werk wat in die SAW gedoen word te bekom sodat werkbeskrywings as fondament kan dien vir die rasionalisering van die personeelfunksie in die SAW. (Projek CONCORDE).

'n Totale houdingsopname jeens die SAW deur alle lede is uitgevoer. (Projek YSBERG).

Verder is ' $n$ bevoegdheidbeoordelingstelsel vir senior offisiere (Kmdt-Brig) ontwikkel ten einde die offisier se potensiaal vir die volgende hoër vlak te bepaal, en 'n volledige verslag van die offisier se loopbaan beskikbaar te stel om aanbevelings te kan maak oor sy toekoms en toekomstige aanwending. 


\section{Fase 4: V-Adm R.A. Edwards, SSAS, SM: Okt 1977 - Jan 1980}

\section{Bevel en beheer}

Gedurende die tydperk 1977 tot 1980 is geen verandering aan die bevel en beheer van die personeelfunksie aangebring nie.

Met die totstandkoming van die Verdedigingsbeplanningkomitee (VBK) kon daar vir die eerste keer ' $n$ personeelinset gelewer word mbt die begroting. Hierdie is as ' $n$ deurbraak mbt die belangrikheid van die personeelfunksie beskou. Die erkenning van die personeelfunksie op daardie vlak het tot 'n groot mate die moontlikheid van foutiewe beplanning, omdat personeel nie in berekening gebring is nie, uitgekanselleer.

\section{Mannekragsituasie}

Die Staandemag het in 1977, 7\% van die Weermag uitgemaak teenoor die gewenste $15,5 \%$ vir daardie tyd. Gedurende die tydperk is die Staandemag egter agv doelgerigte werwing uitgebrei met $28,6 \%$.

Verder was daar egter nog steeds 'n groot verlies aan opgeleide personeel. Hierdie personeel was egter nou nie meer totaal vir die SAW verlore nie aangesien hulle nog diensverpligting gehad het as lede van die Staandemag-Reserwe. Die verlies van opgeleide personeel en die opleiding van hul plaasvervangers het egter ' $n$ addisionele las op die reeds uitgedunde opgeleide lede geplaas.

Die gebrek aan nodige infrastruktuur het ook bygedra tot die onvermoë om die Staandemag ooreenkomstig die projeksies van die OPMANkomitee uit te brei.

\section{Bemanning}

'n Doelgerigte poging om kortdienspersoneel te werf is in 1977 met groot sukses van stapel gestuur.

59. ' $n$ Ooraanbod van werksoekers is ondervind en selektiewe keuring kon toegepas word. Die omset van opgeleide personeel het egter nog daartoe bygedra dat teen Julie 1978 daar nog 'n groot tekort van Staandemag personeel teenoor die OPMAN I vereistes ondervind is. Die OPMAN I gestelde behoefte van 39000 opgeleide Staandemag lede teen Mrt 81 kon teen die einde van 1979 slegs met 28000 lede bevredig word. 'n Verdere ontstellende feit wat na vore gekom het was dat uit die werklike sterkte van die Staandemag:

(a) ongeveer $22 \%$ minder as 1 jaar diens gehad het;

(b) ongeveer $25 \%$ tussen 1 en 2 jaar diens gehad het, dws;

(c) ongeveer $47 \%$ van die Staandemag het minder as 2 jaar diens gehad.

Die OPMAN I verslag het die dringendheid van realistiese Staandemagsterktes beklemtoon, maar die aanbevelings het egter tot geen aksie of resultate gelei wat die paraatheid van die SAW op mannekraggebied verbeter het nie.

Die H SAW het in Januarie 1979 opdrag gegee dat ondersoek ingestel word na 'n meer eweredige verspreiding van die verdediginglas en ' $n$ OPMAN II-komitee is saamgestel om die ondersoek te doen.

Die verslag het aangedui dat, tov die belangrikste aspekte van mannekragvoorsiening $\mathrm{nl}$ diensvoorwaardebepaling in die SAW die bestuur in die hande van funksionarisse van die Staatsdienskommissie was wat nie die verantwoordelikheid gedra het vir die doeltreffende bemanning van die SAW nie. Verder is aanbevelings gemaak mbt die benutting van anderskleuriges en vroue in die SAW.

Die SAW het verder dmv sy personeelfunksie oor hierdie tydperk Weermagte vir onafhanklike state aan die grense van die RSA beplan en beman. Die bydrae van die Afdeling Personeel tot die daarstelling van 'n SWA Weermag het ook oor hirdie tydperk reeds omvangryke afmetings aangeneem.

\section{Instandhouding}

'n SAW beleid tov die aanstelling, bevordering, verplasing ens van anderskleuriges in die SAW, is gepromulgeer.

'n Ondersoek na die personeelfunksie is uitgevoer en vier duidelike komponente het uitgekristaliseer nl:

(a) Die werk. (Werkbeskrywing).

(b) Die werker. (Werkinligting).

(c) Die organisasie.

(d) Die evaluasiestelsel.

Projekte is respektiewelik vir elkeen van hierdie komponente geloods ten einde die personeelfunksie verder te verbeter $\mathrm{nl}$ : 
(a) CONCORDE.

(b) PERSBINS en MATCH.

(c) PERSONEELTABELLE.

(d) YSBERG.

Die werkinformasiestelsel (CONCORDE) was reeds so ver gevorder dat ' $n$ werkerinformasiestelsel (MATCH) geloods kon word wat tesame met PERSBINS alle kwantitatiewe en kwalitatiewe informasie sou verskaf vir sinvolle mannekragbeplanning.

Die verslag oor die instelling van 'n rekenaarorganisasie om die Verdedigingfamilie te bedien is ook gedurende die tydperk deur die Kabinet goedgekeur.

Ten einde mobilisasiebeplanning as deel van die normale werksaamhede van Afdeling Personeel te bedryf is ' $n$ Bestuurskomitee in die lewe geroep waarby die koördinerende mobilisasiekomitee geïntegreer is.

Mbt die loopbaanbeplanning van professionele offisiere in die SAW is die vorderingpatroon wat aan salarisvordering gekoppel is ontkoppel van militêre rangvordering. Terselfdertyd is ' $n$ nuwe bevorderingsbeleid vir offisiere en manskappe in die Staandemag, BM, Kommandos en Hulpdienste gepromulgeer.

Gedurende Adm Edwards se ampstermyn as HSP is die De Munnik-komitee aangestel met die opdrag om ondersoek in te stel en aanbevelings te maak oor ' $n$ nuwe vakmanbedeling vir die SAW. Die doel was om hierdeur ' $n$ poging aan te wend om die uitvloei van opgeleide vakmanne te bekamp.

Wat die rekenarisering van die personeelfunksie betref is daar gedurende hierdie tydperk baie probleme ondervind met oorskakeling sowel as lang rekenaar aftye.

'n Verder mylpaal in die pogings om die Staandemag te bou en retensie van personeel te bewerkstellig was die regstelling van regulasies wat diskriminasie agv taal, ras, kleur of politiek tot gevolg kon hê.

Gedurende Februarie 1978 is personeelbestuur nav ' $n$ beslissing van die VSR verder gedesentraliseer. Hierdie desentralisasie is bewerkstellig deur delegasies te hersien en te promulgeer.

\section{Professionalisering van personeelpraktisyns}

Die gedragvoorskrifte van die personeelpraktisyn was tot 1974 geensins deur wetgewing beskryf nie. Die Wet op geneeshere, tandartse en aanvullende gesondheidberoepe (Wet 56 van 1974) het egter gedragvoorskrifte gestipuleer wat die personeelpraktisyn totaal aan bande gelê het en slegs aan geregistreerde sielkundiges vryheid en toegang tot daaglikse personeelbestuuraktiwiteite verleen het.

Ten einde personeelbestuur professionele erkenning te gee het die Minister van Arbeid toegestem tot 'n Ad Hoc Komitee van Ondersoek oor wetgewing mbt professionele status van personeelpraktisyns. Die SAW se mannekragkonsultant mnr J.J.L. Coetzee is as ondervoorsitter van die komitee aangestel en kapt(SAV) Steyn en kapt(SAV) Eberlein as lede. Verder is lede aangestel wat alle dele van die werkgewersgemeenskap verteenwoordig het. Op aanbeveling van die ad hoc komitee is besluit dat daar wel 'n behoefte is vir die professionalisering van personeelfunksionarisse. Die SA Raad vir Personeelpraktyk is in 1982 gestig en voorgestelde wetgewing vir die registrasie van personeelfunksionarisse by die Raad is vir die 1986 parlementsitting ingedien.

Om hierdie redes is besluit dat die status van die personeelfunksie in die SAW in oënskou geneem moet word. Verder is besef dat dit hoogs bevorderlik vir die personeelfunksie sou wees indien dit deur professionele mense bedryf kon word.

Opdrag is ook gegee om ' $n$ handleiding vir personeeladministrasie op te stel ten einde die personeelfunksie in die SAW te verbeter. ' $n$ Werkgroep het aanvanklik 'n ondersoek gedoen wat uitgeloop het op die ontwikkeling van ' $n$ totale SAW Personeelkode. (SAWPK). Dit is beplan om die kode teen 1 Okt 86 drukgereed te hê.

\section{Fase 5: Lt Genl G.J.J. Boshoff SSA, SD, SM: Feb 1980 - Jan 1981}

\section{Mannekragsituasie}

Net soos ander owerheidsektore het die SAW nog steeds probleme ondervind om personeel te behou. Hoewel syfers ' $n$ surplus getoon het wanneer bedankings en indiensnemings met mekaar vergelyk is het daar in reële terme egter ' $n$ aansienlike verlies aan kundigheid plaasgevind. 
Die burgerlike komponent van die SAW het ' $n$ belangrike deel van die bestuur en administrasie van die SAW gevorm. Die burgerlikes is as ' $n$ belangrike mannekragbron gebruik waaruit tekorte aangevul kon word en die bestaande postestruktuur is uitgebrei om vir hulle sinvoller en voordeliger loopbane daar te stel.

\section{Bemanning}

Die SAW was vir sowel die Voltydse Mag as die Deeltydse Mag hoofsaaklik op die blanke manlike burger as mannekragbron aangewese.

Die Staandemag het op daardie stadium 28\% van die voltydse mag uitgemaak. Grootskaalse vermeerdering kon egter nie geskied alvorens die Staandemag sodanig uitgebou is dat groter getalle hanteer kon word nie. Daar is egter beplan om die Voltydse Mag teen 1987 met ongeveer $17 \%$ uit te brei.

Op 1 Julie 1980 het die H SAW opdrag gegee dat 'n komitee onder voorsitterskap van genl maj R.F. Holtzhausen ondersoek instel na leemtes in die bestaande nasionale dienspligstelsel en aanbevelings maak oor moontlike aanpassings.

Op 11 Sep 80 het die Komitee 'n verslag uitgebring met die volgende aanbevelings:

(a) Gelyke beregtiging moet bewerkstellig word deur aanvanklike opleiding vir essensiële diensposte te verplig en immigrante, vroue, Kleurlinge en Asiërs betrokke te maak. Verder moet 'n groter aanvanklike dienspligmag vir die lopende geveg beskikbaar gestel word en ' $n$ dag-vir-dag kredietstelsel ingestel word.

(b) Die beter benutting en aanwending van Kommandos en NDPs moet verseker word.

(c) Verliese moet teëgewerk word.

(d) Die verlenging van die aanvanklike dienspligtydperk (2 jaar) bied nie die oplossing om magspeile vir die lopende geveg daar te stel nie, maar blyk 'n verlenging van die totale dienspligtydperk ' $n$ oplossing te wees.

Agv ' $n$ effektiewe werwingsprogram kon egter weer daarin geslaag word om meer mense in diens te neem as wat die diens verlaat het.

\section{Mannekraginstandhouding}

Die SAW se groeplewensversekeringskema is ingestel waarvolgens lede van die SAW, terwyl hulle militêre diens verrig, teen dood en ongeskiktheid gedek word.

Die loongaping tussen die verskillende bevolkingsgroepe is sover vernou dat in die meeste ranggroepe pariteit bereik is mbt Kleurlinge, Indiërs en Blankes.

Ten einde die personeelfunksie meer doeltreffend te laat funksioneer is daar gekonsentreer op die verbetering van die administratiewe funksionering dmv groter benutting van die rekenaar.

Daar is ook gedurende hierdie tydperk ' $n$ Personeelretensiestelsel ontwikkel en geïmplementeer ten einde die steeds onstuitbare uitvloei van opgeleide personeel teen te werk. Die stelsel het die volgende behels:

(a) Die voltooiing van ' $n$ uitdienstredingvraelys deur diensverlaters.

(b) Die voer van onderhoude met diensverlaters en voltooiing van 'n uitgangonderhoudvraelys deur die onderhoudvoerder.

(c) Sentrale verwerking van die vraelyste ten einde tendense te bepaal en aanbevelings te maak.

Mbt die SAW se vergoedingstelsel is ' $n$ projek, PROJEK 2000 geloods ten einde die ontwikkeling van ' $n$ vergoedingstelsel te ondersoek en aanbevelings te maak.

Gedurende 1980 is egter ook 'n projek geloods (PROJEK LEMBUS) om rasionalisasie binne die SAW met die klem op 'n kleiner, doeltreffender weermag te ondersoek.

Die eerste fase (PERSOL) van die gerekenariseerde Personeelbestuurinformasiestelsel is gedurende 1980 vir die SAW geïmplementeer. Die Sentrale Meganisasiekomitee by die KvA het beginselgoedkeuring gegee dat opleiding as komponent van rekenarisering beskou word in Infoplan sou betrokke wees in die behoeftebepaling en gepaardgaande opleiding vir die SAW.

\section{Opsomming van tendense}

Bevel en Beheer. Die belangrikheid van die personeelfunksie ten einde ' $n$ konstante parate Weermag daar te stel is deur die geskiedenis as van kardinale belang bevestig. 
Verder is dit duidelik dat die personeelfunksie deur kundige personeelpraktisyns uitgevoer en beheer moet word. Soos die geskiedenis verloop het, het dit duideliker geword dat die personeelfunksie ' $n$ spesialisfunksie is wat genoodsaak dat elke personeelfunksionaris van die laagste tot die hoogste vlak, gespesialiseerde personeelbestuur en - administratiewe opleiding moet hê. Die geskiedenis het dus bevestig dat die personeelfunksie suiwer beheer en bedryf moet word as spesialisfunksie.

Mannekragsituasie. Die geskiedenis vestig die aandag daarop dat alhoewel werwing van rekrute suksesvol kan verloop, die verdediging van die RSA gevaar kan loop om in duie te stort agv die verlies van kundige personeel. Klem sal heel moontlik moet val op retensie van opgeleide personeel.

Tydens ekonomiese insinkings stabiliseer mannekragsituasies maar met daaropvolgende oplewings verloor die Weermag weer, meer spesifiek opgeleide personeel ten gunste van die privaatsektor.

Bemanning. Ten einde die eskalerende bedreiging teen die RSA die hoof te bied is dit noodsaaklik om die Staandemag tekorte aan te vul deur elke medies geskikte burger te betrek vir diens ter verdediging van sy/haar vaderland.

Instandhouding. Beroepsdifferensiasie het homself gevestig as begrip sowel as 'n metode van personeelbestuur en -administrasie in die RSA. Dit het duidelik geword dat diensvoordele en -voorwaardes in terme van die markwaarde van elke gediffirensieerde beroepsgroep gemaak sal moet word om moontlik beter personeelretensie te bewerkstellig.
Agv tegnologiese ontwikkeling en uitbreiding van die SAW het dit al meer noodsaaklik geword dat personeeladministrasie gerekenariseer word ten einde die personeelfunksie doeltreffend te bedryf.

Akkurate werkbeskrywings het 'n noodsaaklikheid geword vir die rasionalisering van die personeelfunksie, bevoegdheidsbeoordeling, bepaling van opleidingsbehoeftes en mannekragbeplanning.

'n Verdere gevolg van die uitbreiding van die Weermag was dat voortdurende delegasie van gesag genoodsaak is ten einde personeelbestuur te desentraliseer om doeltreffendheid te verhoog.

\section{Bibliografie:}

1. Broekman M. 1979 Concorde: Verkry 'n Houvas op Personeel. Militaria 9/1 p.24-26.

2. Dept Verdediging. Jaarverslae 1913-1957.

3. Dept Verdediging. Korrespondensie Militêre Sekretaris 1939-46. MS 18 Vol $1-3$.

4. Dept Verdediging. Witskritte 1964-1982.

5. Edwards R.A. V-Adm Persoonlike Onderhoud.

6. Grobler J.E.H. 1977. Die Administratiewe Dienskorps. Militaria 7/3 p. $18-29$.

7. Hartzenberg C.H. Veggenl Persoonlike Onderhoud.

8. Hiemstra R.C. Kmdt genl. Persoonlike Onderhoud.

9. Le Grange P.A. Lt genl. Persoonlike Onderhoud.

10. Markgraat G.H.F. Genl maj. Persoonlike Onderhoud.

11. SAW AG. Lêer $527 / 7 \mathrm{Vol} 1$.

12. SAW AG. Lêers $527 / 15$ Vol $1-3$.

13. SAW AG. Lêer $527 / 16$ Vol 1.

14. SAW HSP. Lêers $521 / 3 / 1 / 2 / 9$ Vol $1-13$.

15. SAW HSP. OPMAN I Verslag 1976.

16. SAW HSP. OPMAN II Verslag 1979

17. SAW HSP/D Man P/G/101/1/B NDP2 Verslag. 1980.

18. Union Office of Census and Statistics Pta 1949. Official Year Book of the Union of SA. Chap XXIX.

19. Von Moltke R. 1982. Die Ontstaan en Ontwikkeling van die Stafafdeling Hoof van Staf Personeel. Militaria 12/2 p.46-51. 